\title{
A Journey with
}

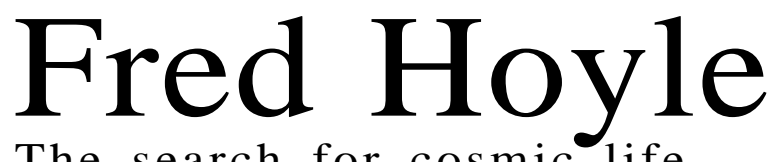

The search for cosmic life 
This page intentionally left blank 


\section{A Journey with Fred Hoyle The search for cosmic life}

\section{Chandra Wickramasinghe}

Cardiff University, $U K$

edited by Kamala Wickramasinghe 


\section{Published by}

World Scientific Publishing Co. Pte. Ltd.

5 Toh Tuck Link, Singapore 596224

USA office: 27 Warren Street, Suite 401-402, Hackensack, NJ 07601

UK office: 57 Shelton Street, Covent Garden, London WC2H 9HE

\section{British Library Cataloguing-in-Publication Data}

A catalogue record for this book is available from the British Library.

\section{A JOURNEY WITH FRED HOYLE The Search for Cosmic Life}

Copyright (C) 2005 by World Scientific Publishing Co. Pte. Ltd.

All rights reserved. This book, or parts thereof, may not be reproduced in any form or by any means, electronic or mechanical, including photocopying, recording or any information storage and retrieval system now known or to be invented, without written permission from the Publisher.

For photocopying of material in this volume, please pay a copying fee through the Copyright Clearance Center, Inc., 222 Rosewood Drive, Danvers, MA 01923, USA. In this case permission to photocopy is not required from the publisher.

ISBN 981-238-911-3

ISBN 981-238-912-1 (pbk)

Typeset by Stallion Press

E-mail: enquiries@stallionpress.com

Printed in Singapore. 
To Priya, whose steadfast support was a source of supreme strength 
This page intentionally left blank 


\section{Foreword}

This is an autobiographical account of a remarkable collaboration between two of the best known astronomers of our time - Chandra Wickramasinghe and the late Sir Fred Hoyle. Chandra's early life in Sri Lanka forms the backdrop for a remarkable scientific contribution of the 20th century. Investigations of the composition of cosmic dust begun in the 1960s led Wickramasinghe and Hoyle to the unlikely conclusion that the Universe is teeming with microbial life, and that such life can be transported from one cosmic location to another. Seen from this point of view, we are part of a connected chain of being that extends from the Earth to the far reaches of the Universe. Science fiction writers have for decades talked about our genes coming from stardust. Diligent and painstaking research over 30 years has turned a once heretical idea into mainstream science. It is a case of science fiction turning into science fact.

Ironically, Sir Fred developed this idea in his science fiction novel The Black Cloud. What a pity he did not live to see its possible realization.

Sir Arthur C. Clarke Fellow, King's College, London 
This page intentionally left blank 


\section{Contents}

Foreword vii

Prologue xi

Chapter 1 Origins: Prelude to the Journey 1

$\begin{array}{lll}\text { Chapter } 2 & \text { Cambridge and a First Meeting } & 11\end{array}$

Chapter $3 \quad$ A Hike in the Lake District 19

$\begin{array}{lll}\text { Chapter } 4 \quad \text { Betwixt the Stars } & 29\end{array}$

Chapter $5 \quad$ The Route to Carbon Dust 37

$\begin{array}{lll}\text { Chapter } 6 & \text { A Theory Takes Shape } & 47\end{array}$

Chapter 7 The Institute of Astronomy: The Vintage Years 53

$\begin{array}{lll}\text { Chapter } 8 & \text { Winds of Change } & 61\end{array}$

$\begin{array}{lll}\text { Chapter } 9 & \text { The Cardiff Era } & 69\end{array}$

$\begin{array}{lll}\text { Chapter } 10 & \text { The Search for Cosmic Life } & 77\end{array}$

Chapter 11 Life from Comets and Pathogens from Space 95 
Chapter 12 First Signs of Life

Chapter 13 Bacterial Dust Predictions Verified

Chapter 14 Life on the Planets

Chapter 15 Evolution from Space

Chapter 16 Theories of Trial

Chapter 17 A Fossil Controversy

Chapter 18 Comet Halley and its Legacy

Chapter 19 Alternative Cosmologies

Bibliography 


\section{Prologue}

Harmony:

The stars shine

I gaze at them.

Among a myriad stars

I stand alone

And wonder

How much life

And love

There was tonight.

Written by the author in 1956

After Fred Hoyle had published his second volume of autobiography entitled: "Home is where the wind blows" he told me on one of his last visits to Cardiff:

"I have made only a passing reference to our long collaboration, because it seemed disjoint from the thesis I was developing there. Ours is an even bigger story that is certainly worth telling. Perhaps you would like to do that some day?"

The journey described in this book leads to an inescapable truth about the origins of life — humans, animals, plants and indeed all life on Earth share a cosmic ancestry. Our genetic heritage is derived from the wider universe; our genes neatly packaged within bacteria came from space.

This radical position was by no means rashly conceived. The long series of steps, over four decades, in reaching it were taken with 
utmost caution and always with a measure of trepidation. Every single unorthodox step was taken only after more conservative alternatives were carefully evaluated. A suite of ideas concerning the cosmic nature of life that was considered outrageously heretical twenty-five years ago, is now sliding imperceptibly into the domain of orthodox science.

Yet the word "panspermia", the concept that life - actual and potential - pervades our universe has its origins in classical Greece and dates back to the pre-Socratic philosopher Anaxoragas (c 500428 BC) who posited that living seeds or "spermata" have been everpresent in the Universe. In India, in Vedic traditions that go back still further (c $1200 \mathrm{BC}$ ), the notion of life being an ever-present cosmic attribute is well-chronicled. These ideas had little impact in the development of Western philosophy, however. The philosophy of Aristotle (c 384-322 BC), based on empiricism, gave the Earth a position distinct from the rest of the Universe, which was thought of as an intangible abstract concept not amenable to reasonable study. Aristotelean ideas that dominated Western thought for centuries included the doctrine of the spontaneous generation of Earth-based life. Fireflies, for instance, were said to emerge from a mixture of warm earth and morning dew, a fanciful explanation which was nonetheless held as irrefutable fact.

The idea of spontaneous generation received its first serious challenge in the 1860's with the work of Louis Pasteur (1822-1895), which suggested that even the very simplest known organisms could not arise independently of a parent organism. This led to the view that each generation of every plant or animal present today must be preceded by an earlier generation of that plant or animal. The same causal link, including the effects of evolution, must persist all the way through the record of fossils and microfossils on the Earth, to the moment when the first microbial life appears. The fact that we now know this moment to have occurred during an epoch of intense cometary bombardment some 3.8-4 billion years ago, possibly means that the life-from-life connection could be extended to a time before the Earth itself existed. This logical outcome of Pasteur's life-fromlife paradigm was recognised by several distinguished scientists in 
the latter part of the nineteenth century, notably John Tyndall, Lord Kelvin and Hermann von Helmholtz. Helmholtz' succinct summary of his position speaks eloquently for them all:

"It appears to me to be fully correct scientific procedure, if all our attempts fail to cause the production of organisms from non-living matter, to raise the question whether life has ever arisen, whether it is not just as old as matter itself, and whether seeds have not been carried from one planet to another and have developed everywhere where they have fallen on fertile soil..."

(H. von Helmholtz in Handbuch de Theoretische Physik, Vol. 1, Braunschweig, 1874)

Despite this early advocacy of panspermia, it was Svante Arrhenius (1859-1927) who first elaborated upon the idea in a quantitative way, and adduced evidence for survival of spores, whilst also proposing an explicit mechanism for interstellar transport (Svante Arrhenius, Worlds in the Making, Harpers, London 1908).

Arrhenius' ideas quickly fell into disfavour partly because it was felt that microorganisms could not be expected to withstand space conditions, and partly because the theory was regarded as intrinsically untestable. The former objection has turned out to be largely false - bacteria are incredibly space-hardy, but the latter point concerning lack of testability remains an issue in Arrhenius' rendering of panspermia. The claim that four billion years ago life on Earth evolved from a primordial seed or spore from space is not testable. But if it could be demonstrated that living seeds still reach the Earth from space, the essence of his theory would be vindicated. Arrhenius asserted that the process he described would be exceedingly difficult, if not impossible, to detect. Science does not look kindly on untestable hypotheses, so Arrhenius' version of panspermia was destined to fall on fallow ground.

Our own approach to the theory of cosmic life, seventy years later, led us at every stage to propositions that were imminently testable or verifiable. Very many of our predictions have indeed been verified, and a multitude of other tests are now in progress. 